\title{
Optimization of Two-Step Acid-Catalyzed Hydrolysis of Oil Palm Empty Fruit Bunch for High Sugar Concentration in Hydrolysate
}

\author{
Dongxu Zhang, ${ }^{1,2}$ Yee Ling Ong, ${ }^{1} \mathrm{Zhi} \mathrm{Li}^{2}$ and Jin Chuan Wu ${ }^{1}$ \\ ${ }^{1}$ Institute of Chemical \& Engineering Sciences (ICES), Agency for Science, Technology and Research (A*STAR), 1 Pesek Road, \\ Jurong Island, Singapore 627833 \\ ${ }^{2}$ Department of Chemical and Biomolecular Engineering, National University of Singapore, 4 Engineering Drive 4, Singapore 117576
}

Correspondence should be addressed to Zhi Li; chelz@nus.edu.sg and Jin Chuan Wu; wu_jinchuan@ices.a-star.edu.sg

Received 10 December 2013; Accepted 18 May 2014; Published 11 June 2014

Academic Editor: Doraiswami Ramkrishna

Copyright (C) 2014 Dongxu Zhang et al. This is an open access article distributed under the Creative Commons Attribution License, which permits unrestricted use, distribution, and reproduction in any medium, provided the original work is properly cited.

\begin{abstract}
Getting high sugar concentrations in lignocellulosic biomass hydrolysate with reasonable yields of sugars is commercially attractive but very challenging. Two-step acid-catalyzed hydrolysis of oil palm empty fruit bunch (EFB) was conducted to get high sugar concentrations in the hydrolysate. The biphasic kinetic model was used to guide the optimization of the first step dilute acidcatalyzed hydrolysis of EFB. A total sugar concentration of $83.0 \mathrm{~g} / \mathrm{L}$ with a xylose concentration of $69.5 \mathrm{~g} / \mathrm{L}$ and a xylose yield of $84.0 \%$ was experimentally achieved, which is in well agreement with the model predictions under optimal conditions $\left(3 \% \mathrm{H}_{2} \mathrm{SO}_{4}\right.$ and $1.2 \% \mathrm{H}_{3} \mathrm{PO}_{4}$, w/v, liquid to solid ratio $3 \mathrm{~mL} / \mathrm{g}, 130^{\circ} \mathrm{C}$, and $36 \mathrm{~min}$ ). To further increase total sugar and xylose concentrations in hydrolysate, a second step hydrolysis was performed by adding fresh $\mathrm{EFB}$ to the hydrolysate at $130^{\circ} \mathrm{C}$ for $30 \mathrm{~min}$, giving a total sugar concentration of $114.4 \mathrm{~g} / \mathrm{L}$ with a xylose concentration of $93.5 \mathrm{~g} / \mathrm{L}$ and a xylose yield of $56.5 \%$. To the best of our knowledge, the total sugar and xylose concentrations are the highest among those ever reported for acid-catalyzed hydrolysis of lignocellulose.
\end{abstract}

\section{Introduction}

Holocellulose sugars in lignocellulosic biomass are rich sources to produce a variety of products by microbial fermentations. Oil palm empty fruit bunch (EFB), a lignocellulosic waste produced during palm oil extraction, has attracted much attention as an abundant lignocellulosic feedstock especially in Southeast Asia [1, 2]. EFB is composed of cellulose (40-60\%), hemicellulose (20-30\%), and lignin (10$20 \%)$ with xylan being the major component of hemicelluloses [3-5]. The cellulose and hemicellulose (collectively holocellulose) components of EFB can be hydrolyzed to monomer sugars by pretreatment and enzymatic hydrolysis $[1,6]$.

Dilute acid-catalyzed hydrolysis of lignocellulose is one of the most frequently investigated pretreatment methods due to its promising commercial feasibility $[7,8]$. Xylan, the major component of hemicelluloses, is very susceptible to dilute acid treatment due to its amorphous structure compared to the highly crystallized cellulose [7]. After acidcatalyzed hydrolysis, most of hemicellulose components are solubilized in hydrolysate as monomer sugars, leaving the solid fraction comprised primarily of cellulose, which is easily hydrolyzed by cellulases to release glucose.

For fermentation processes, usually a high concentration of sugars is necessary to get high product titer for costeffective product separation. However, for acid-catalyzed hydrolysis of lignocellulose, the reported sugar concentrations in the hydrolysates were usually at $20-60 \mathrm{~g} / \mathrm{L}$ [9-11]. These sugar concentrations are far from the industrially accepted levels of over $100 \mathrm{~g} / \mathrm{L}$ for fermentations [12-14]. To obtain high sugar concentrations in hydrolysate, a low liquid to solid ratio (LSR) is necessary. However, the sugar yield is often reduced at high solid loadings. Therefore, it is very challenging to get high sugar concentrations in hydrolysates but still keep good sugar yields.

Here we report a two-step process for acid-catalyzed hydrolysis of EFB to get high sugar concentrations (>110 g/L) 


$$
\text { Seaman model } \quad \text { Xylan }(H) \stackrel{k_{1}}{\longrightarrow} \quad \text { Xylose }(X) \stackrel{k_{2}}{\longrightarrow} \operatorname{Furfural}(F)
$$$$
\text { Biphasic model } \quad \text { Fast-hydrolysis Xylan }\left(H_{f}\right)
$$

SCHEME 1

in the hydrolysate with reasonable sugar yields. The EFB hydrolysis was simulated by a kinetic model to guide the process optimization. To the best of our knowledge, this is the first report that sugar concentrations of over $100 \mathrm{~g} / \mathrm{L}$ were directly obtained from acid-catalyzed pretreatment of lignocellulose without any additional concentration steps.

\section{Materials and Methods}

2.1. Raw Materials. EFB (moisture content 7\%, w/w) was kindly provided by Wilmar International Limited, Singapore. It was sun-dried and grinded to small particles by a knife mill with $1 \mathrm{~mm}$ screen (unless otherwise specified), followed by oven-drying at $80^{\circ} \mathrm{C}$ overnight before use. EFB compositions were analyzed following the standard procedures of NREL [17]. For getting EFB particles of different sizes, $2 \mathrm{~mm}, 4 \mathrm{~mm}$, and $8 \mathrm{~mm}$ screens were used, respectively.

2.2. Acid Hydrolysis. Acid-catalyzed hydrolysis of EFB was carried out in $1 \mathrm{~L}$ Parr reactors (Fike, Blue Springs, MO, USA). EFB ( $45 \mathrm{~g}$ ) was added to $135 \mathrm{~mL}$ water containing 1.5$3 \%(\mathrm{w} / \mathrm{v})$ of $\mathrm{H}_{2} \mathrm{SO}_{4}$ or $0.6-1.2 \%(\mathrm{w} / \mathrm{v})$ of $\mathrm{H}_{3} \mathrm{PO}_{4}$ or both. The temperature was raised to predetermined levels (120$140^{\circ} \mathrm{C}$ ) for hydrolyses. After reaching the required reaction time, the reaction mixture was immediately cooled down to room temperature by circulated cooling water. The solid was separated from the liquid phase by filtration and the filtrate was analyzed by HPLC.

2.3. Analytical Methods. Xylose, glucose, arabinose, and acetic acid were analyzed by HPLC (LC-10AT, refractive index detector SPD-10A, Shimadzu, Kyoto, Japan) with a Bio-Rad Aminex HPX-87 H column (Bio-Rad, Herculse, CA, USA) at $50^{\circ} \mathrm{C}$. The mobile phase was $5 \mathrm{mM} \mathrm{H}_{2} \mathrm{SO}_{4}$ at $0.65 \mathrm{~mL} / \mathrm{min}$.

2.4. Mathematic Description of Kinetic Model. Mathematic models have been widely accepted to describe the kinetics of lignocellulose hydrolysis [18-20]. Our previous study showed that the biphasic model can better describe the acid-catalyzed hydrolysis of xylan in EFB [4] than do the Saeman model [21]. So the biphasic model was selected to guide the optimization of the two-step acid-catalyzed hydrolysis of xylan in
EFB. The biphasic model is described as shown in Scheme 1 $[22,23]$.

This model assumes that one part of the hemicellulose fraction tends to hydrolyze faster (fast hydrolysis) than the other part (slow hydrolysis) [24]. The fast and slow hydrolysis fractions differ only slightly per substrate and typically account for about $65 \%$ and $35 \%$, respectively [22]. This kinetic model suggests that acid concentration, temperature, and reaction time should be synergistically adjusted to favor xylose accumulation by minimizing sugar degradation $[22,23]$. The mathematical description of this model is as follows $[22,23]$ :

$$
\begin{gathered}
\frac{d\left[H_{f}\right]}{d t}=-k_{1 f}\left[H_{f}\right], \\
\frac{d\left[H_{s}\right]}{d t}=-k_{1 s}\left[H_{s}\right], \\
\frac{d[X]}{d t}=k_{1 f}\left[H_{f}\right]+k_{1 s}\left[H_{s}\right]-k_{2}[X], \\
\frac{d[F]}{d t}=k_{2}[X], \\
\frac{k_{1 f}\left[H_{f}\right]_{0}}{k_{2}-k_{1 f}}\left[\exp \left(-k_{1 f} t\right)-\exp \left(-k_{2} t\right)\right] \\
+\frac{k_{1 s}\left[H_{s}\right]_{0}}{k_{2}-k_{1 s}}\left[\exp \left(-k_{1 s} t\right)-\exp \left(-k_{2} t\right)\right],
\end{gathered}
$$

where $[H]$ represents the total xylan concentration; $\left[H_{f}\right]$ and $\left[H_{s}\right]$ are the concentrations of fast and slow hydrolytic xylan, respectively $\left(\left[H_{f}\right]_{0}+\left[H_{s}\right]_{0}=[H]_{0}\right) ;[X]$ and $[F]$ denote the concentrations of xylose and furfural, respectively $\left([X]_{0}=\right.$ $\left.0,[F]_{0}=0\right) ; k_{1 f}$ and $k_{1 s}$ are the rate constants of fast and slow xylan hydrolysis, respectively; $k_{2}$ is the rate constant of xylose degradation.

Estimation of kinetic parameters to fit the nonlinear model for EFB hydrolysis was conducted with MATLAB R 2010b (The MathWorks, Inc., Natick, MA). Accountability of the estimated parameters was evaluated by statistical analysis, with which the determination coefficient $\left(R^{2}\right)$ was obtained. 


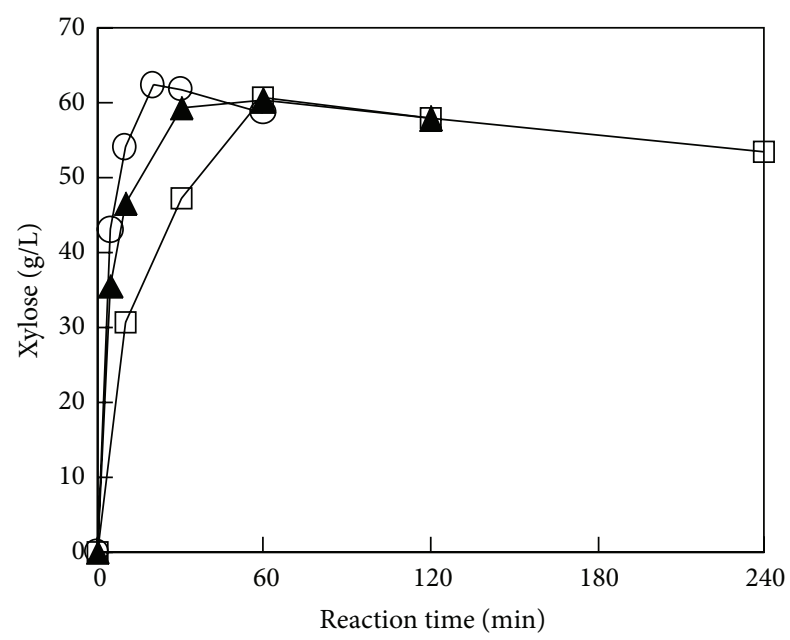

Figure 1: Time courses of xylose concentration at different temperatures. $\square: 120^{\circ} \mathrm{C} ; \mathbf{\Delta}: 130^{\circ} \mathrm{C}$; O: $140^{\circ} \mathrm{C}$. Other conditions: $2 \%(\mathrm{w} / \mathrm{v})$ $\mathrm{H}_{2} \mathrm{SO}_{4}$ and $0.8 \%(\mathrm{w} / \mathrm{v}) \mathrm{H}_{3} \mathrm{PO}_{4}$, liquid to solid ratio $3 \mathrm{~mL} / \mathrm{g}$.

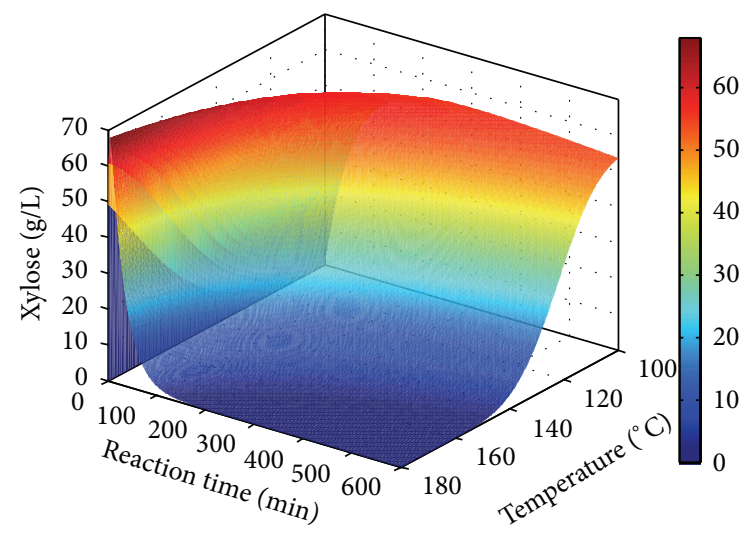

FIgURE 2: Predicted 3-dimentional changes of xylose concentration at different temperatures by biphasic model. Assumed conditions: $2 \%(\mathrm{w} / \mathrm{v}) \mathrm{H}_{2} \mathrm{SO}_{4}$ and $0.8 \%(\mathrm{w} / \mathrm{v}) \mathrm{H}_{3} \mathrm{PO}_{4}$, liquid to solid ratio $3 \mathrm{~mL} / \mathrm{g}$, $100-180^{\circ} \mathrm{C}$

\section{Results and Discussion}

3.1. Composition of EFB. The compositions of oven-dried EFB were determined to be $34.3 \pm 0.6 \%$ of glucan, $21.8 \pm 0.3 \%$ of xylan, $21.5 \pm 0.4 \%$ of Klason lignin, and $22.4 \pm 1.0 \%$ of others [4], which are very similar to those reported by Rahman et al. [1]. The theoretical yield of xylose from EFB was thus calculated to be $24.8 \mathrm{~g} / 100 \mathrm{~g}$ EFB. Therefore, the theoretical xylose concentration is $82.7 \mathrm{~g} / \mathrm{L}$ at a liquid to solid ratio of $3 \mathrm{~mL} / \mathrm{g}$.

\subsection{Effect of Temperature on EFB Hydrolysis at Low Liquid to} Solid Ratio. EFB hydrolysis was first conducted at $120-140^{\circ} \mathrm{C}$ using $2 \%(\mathrm{w} / \mathrm{v})$ of $\mathrm{H}_{2} \mathrm{SO}_{4}$ and $0.8 \%(\mathrm{w} / \mathrm{v})$ of $\mathrm{H}_{3} \mathrm{PO}_{4}$ to get the xylose concentration profile in the hydrolysate (Figure 1). The values of $k_{1 f}, k_{1 s}, k_{2}$, and $R^{2}$ at different temperatures were obtained using the software MATLAB R 2010b and listed in

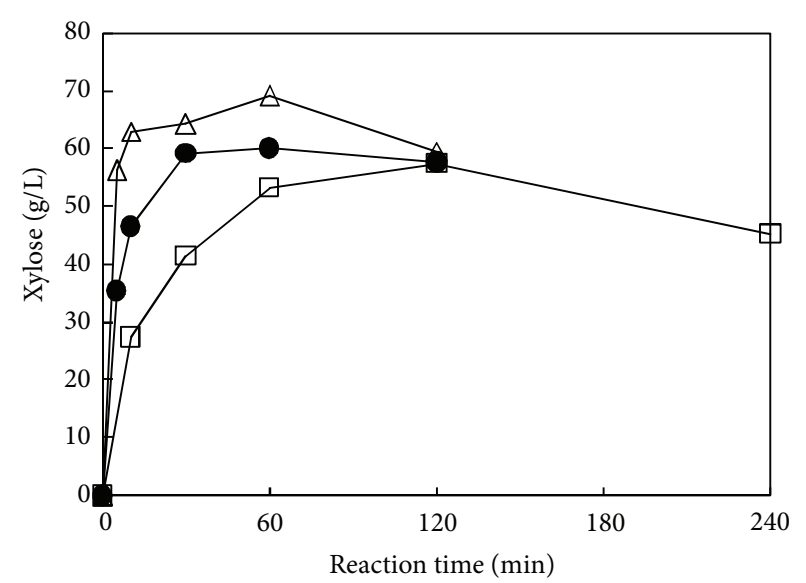

Figure 3: Time courses of xylose yield at different acid concentrations. $\square$ : $1.5 \%(\mathrm{w} / \mathrm{v}) \mathrm{H}_{2} \mathrm{SO}_{4}$ and $0.6 \%(\mathrm{w} / \mathrm{v}) \mathrm{H}_{3} \mathrm{PO}_{4} ; \bullet: 2 \%(\mathrm{w} / \mathrm{v})$ $\mathrm{H}_{2} \mathrm{SO}_{4}$ and $0.8 \%(\mathrm{w} / \mathrm{v}) \mathrm{H}_{3} \mathrm{PO}_{4} ; \triangle: 2.5 \%(\mathrm{w} / \mathrm{v}) \mathrm{H}_{2} \mathrm{SO}_{4}$ and $1 \%(\mathrm{w} / \mathrm{v})$ $\mathrm{H}_{3} \mathrm{PO}_{4}$. Other conditions: liquid to solid ratio $3 \mathrm{~mL} / \mathrm{g}, 130^{\circ} \mathrm{C}$.

Table 1 . The rate constants $\left(k_{1 f}, k_{1 s}\right.$, and $\left.k_{2}\right)$ in the biphasic model are assumed to follow the classical Arrhenius equation:

$$
k=A \exp \left(-\frac{E_{a}}{R T}\right) \min ^{-1} .
$$

To obtain $E_{a}, \ln (k)$ was plotted against $T^{-1}$ (data not shown). The $E_{a}$ values for the fast and slow hydrolysis reactions were calculated to be $89.1 \mathrm{~kJ} / \mathrm{mol}$ and $99.7 \mathrm{~kJ} / \mathrm{mol}$, respectively. Similarly, the $E_{a}$ value for the sugar degradation reaction was determined to be $73.9 \mathrm{~kJ} / \mathrm{mol}$. The $E_{a}$ values of the fast hydrolysis reaction, slow hydrolysis reaction, and xylose degradation reaction are lower than most of the reported values $[23,25]$, which might be ascribed to the differences in lignocellulose compositions and acids used. Based on the $E_{a}$ values obtained above, the $k$ values for the biphasic model can be described as follows:

$$
\begin{aligned}
& k_{1 f}=5.28 \times 10^{10} \exp \left(-\frac{89.1}{R T}\right) \mathrm{min}^{-1}, \\
& k_{1 s}=1.18 \times 10^{11} \exp \left(-\frac{99.7}{R T}\right) \mathrm{min}^{-1}, \\
& k_{2}=1.18 \times 10^{7} \exp \left(-\frac{73.9}{R T}\right) \mathrm{min}^{-1}
\end{aligned}
$$

The predicted results based on the biphasic model are depicted in Figure 2. It is seen that a high reaction temperature leads to an increase in optimal xylose concentration and a decrease in the required reaction time for achieving the highest xylose concentration. High xylose concentrations $(>60 \mathrm{~g} / \mathrm{L})$ are achievable at $130-180^{\circ} \mathrm{C}$.

3.3. Effect of Acid Concentration on EFB Hydrolysis at Low Liquid to Solid Ratio. In order to correlate the kinetic parameters $k_{1 f}, k_{1 s}$, and $k_{2}$ with acid concentration, experiments were conducted at $130^{\circ} \mathrm{C}$ to get the required data (Figure 3 ). 
TABLE 1: Estimated kinetic parameters of biphasic model at different temperatures and acid concentrations.

\begin{tabular}{|c|c|c|c|c|c|}
\hline & & $k_{1 f}\left(\min ^{-1}\right)$ & $k_{1 s}\left(\min ^{-1}\right)$ & $k_{2}\left(\min ^{-1}\right)$ & $R^{2}$ \\
\hline \multirow{3}{*}{ Temperature $\left({ }^{\circ} \mathrm{C}\right)$} & 120 & $6.92 \times 10^{-2}$ & $7.20 \times 10^{-3}$ & $1.90 \times 10^{-3}$ & 0.990 \\
\hline & 130 & $1.89 \times 10^{-1}$ & $1.27 \times 10^{-2}$ & $2.70 \times 10^{-3}$ & 0.998 \\
\hline & 140 & $2.58 \times 10^{-1}$ & $3.16 \times 10^{-2}$ & $5.70 \times 10^{-3}$ & 0.999 \\
\hline \multirow{3}{*}{ Acid concentration $(\mathrm{w} / \mathrm{v})$} & $1.5 \% \mathrm{H}_{2} \mathrm{SO}_{4}+0.6 \% \mathrm{H}_{3} \mathrm{PO}_{4}$ & $5.17 \times 10^{-2}$ & $6.70 \times 10^{-3}$ & $2.60 \times 10^{-3}$ & 0.981 \\
\hline & $2 \% \mathrm{H}_{2} \mathrm{SO}_{4}+0.8 \% \mathrm{H}_{3} \mathrm{PO}_{4}$ & $1.89 \times 10^{-1}$ & $1.27 \times 10^{-2}$ & $2.70 \times 10^{-3}$ & 0.998 \\
\hline & $2.5 \% \mathrm{H}_{2} \mathrm{SO}_{4}+1 \% \mathrm{H}_{3} \mathrm{PO}_{4}$ & $7.56 \times 10^{-1}$ & $3.45 \times 10^{-2}$ & $2.90 \times 10^{-3}$ & 0.995 \\
\hline
\end{tabular}

TABLE 2: Estimated $n$ and $k_{0}$ for $k_{1 f}, k_{1 s}$, and $k_{2}$.

\begin{tabular}{lccc}
\hline & $n$ & $k_{0}\left(\mathrm{~min}^{-1}\right)$ & Slope $R^{2}$ \\
\hline$k_{1 f}$ & 5.22 & $1.60 \times 10^{28}$ & 0.991 \\
$k_{1 s}$ & 3.16 & $3.16 \times 10^{21}$ & 0.961 \\
$k_{2}$ & 0.21 & $5.20 \times 10^{7}$ & 0.939 \\
\hline
\end{tabular}

The rate constants $\left(k_{1 f}, k_{1 s}\right.$, and $\left.k_{2}\right)$ in the biphasic model are assumed to follow the modified Arrhenius equation [23]:

$$
k=k_{0}\left[H^{+}\right]^{n} \exp \left(-\frac{E_{a}}{R T}\right) \min ^{-1},
$$

where $\left[\mathrm{H}^{+}\right](\mathrm{mol} / \mathrm{g})$ represents the number of moles of aqueous hydronium ion per unit weight of EFB. The $\mathrm{H}^{+}$ concentration was measured to be $0.040 \mathrm{M}$ using $0.5 \%(\mathrm{w} / \mathrm{v})$ of $\mathrm{H}_{2} \mathrm{SO}_{4}$ and $0.2 \%(\mathrm{w} / \mathrm{v})$ of $\mathrm{H}_{3} \mathrm{PO}_{4}$ as the catalysts. At the liquid to solid ratio of $3 \mathrm{~mL} / \mathrm{g},\left[\mathrm{H}^{+}\right]$can be expressed as 4.0 $\times 10^{-5} \times 3(\mathrm{~mol} / \mathrm{g})$. Therefore, when the acid dosage used is $D$ times of the concentration of using $0.5 \%(\mathrm{w} / \mathrm{v})$ of $\mathrm{H}_{2} \mathrm{SO}_{4}$ and $0.4 \%(\mathrm{w} / \mathrm{v})$ of $\mathrm{H}_{3} \mathrm{PO}_{4},\left[\mathrm{H}^{+}\right]$can be expressed as $4.0 \times 10^{-5} \times 3$ $\times D(\mathrm{~mol} / \mathrm{g})$.

The values of $k_{1 f}, k_{1 s}, k_{2}$, and $R^{2}$ were obtained using the software MATLAB R $2010 \mathrm{~b}$ and listed in Table 1 . Then $\ln (k)$ was plotted against $\ln \left[\mathrm{H}^{+}\right]$(data not shown) to get the $n$ and $k_{0}$ values corresponding to $k_{1 f}, k_{1 s}$, and $k_{2}$ (Table 2 ).

Based on the above parameters, the $k$ values for the biphasic model can be described as follows:

$$
\begin{gathered}
k_{1 f}=1.57 \times 10^{28}\left[H^{+}\right]^{5.22} \exp \left(-\frac{89.1}{R T}\right) \mathrm{min}^{-1}, \\
k_{1 s}=3.16 \times 10^{21}\left[H^{+}\right]^{3.16} \exp \left(-\frac{99.7}{R T}\right) \mathrm{min}^{-1}, \\
k_{2}=3.40 \times 10^{6}\left[H^{+}\right]^{0.21} \exp \left(-\frac{73.9}{R T}\right) \mathrm{min}^{-1} .
\end{gathered}
$$

Now the xylose yields at different acid concentrations can be calculated based on (5) (Figure 4). It is seen that an optimal xylose concentration of $70 \mathrm{~g} / \mathrm{L}$ is able to be achieved at the liquid to solid ratio of $3 \mathrm{~mL} / \mathrm{g}$. The optimal xylose concentration increases with increasing acid concentration. The decrease in reaction temperature does not significantly affect the xylose yield at high acid concentrations. A xylose concentration of $69.5 \pm 1.5 \mathrm{~g} / \mathrm{L}$ (corresponding to a xylose yield of $84.0 \pm 1.8 \%$ ) and a total sugar concentration of $83.0 \pm 1.9 \mathrm{~g} / \mathrm{L}$ in the hydrolysate were experimentally achieved under the optimal conditions $\left(3 \% \mathrm{H}_{2} \mathrm{SO}_{4}\right.$ and $1.2 \% \mathrm{H}_{3} \mathrm{PO}_{4}$, w/v, liquid to solid ratio $3 \mathrm{~mL} / \mathrm{g}, 130^{\circ} \mathrm{C}$, and $36 \mathrm{~min}$ ) as predicted by the biphasic model. The concentrations of acetic acid, furfural, and HMF are $16.2 \pm 0.2,2.3 \pm 0.2$, and $0.2 \pm 0.1 \mathrm{~g} / \mathrm{L}$, respectively. The total sugar and xylose concentrations are the highest ever reported for acid-catalyzed hydrolysis of lignocellulose owing to the use of a low liquid to solid ratio under the optimized conditions (Table 3) $[1,9,11,15]$.

3.4. Two-Step Hydrolysis of EFB. To further increase xylose concentration in the hydrolysate, a two-step hydrolysis strategy was applied. Into the hydrolysates obtained at different acid concentrations $\left(2-3 \% \mathrm{H}_{2} \mathrm{SO}_{4}\right.$ and $0.8-1.2 \% \mathrm{H}_{3} \mathrm{PO}_{4}$, w/v) was added fresh EFB for second step hydrolysis under the optimal conditions. The biphasic model predicts the optimal reaction times for the first step as $36 \mathrm{~min}$ for $3 \% \mathrm{H}_{2} \mathrm{SO}_{4}$ and 0.8-1.2\% $\mathrm{H}_{3} \mathrm{PO}_{4}, 49 \mathrm{~min}$ for $2.5 \% \mathrm{H}_{2} \mathrm{SO}_{4}$ and $1 \% \mathrm{H}_{3} \mathrm{PO}_{4}$, and $64 \mathrm{~min}$ for $3 \% \mathrm{H}_{2} \mathrm{SO}_{4}$ and $0.8-1.2 \% \mathrm{H}_{3} \mathrm{PO}_{4}$, respectively, which were used to prepare the hydrolysates at $130^{\circ} \mathrm{C}$ and a LSR of $3 \mathrm{~mL} / \mathrm{g}$. The hydrolysates thus obtained were then mixed with fresh EFB for hydrolysis at $130^{\circ} \mathrm{C}$ and a LSR of $3 \mathrm{~mL} / \mathrm{g}$ for different times. As shown in Figure 5, the xylose concentration was further increased with increasing acid concentration. A total sugar concentration of $114.4 \mathrm{~g} / \mathrm{L}$ and a xylose concentration of $93.5 \mathrm{~g} / \mathrm{L}$ with a xylose yield of $56.5 \%$ were experimentally achieved under the optimal conditions of $3 \%(\mathrm{w} / \mathrm{v}) \mathrm{H}_{2} \mathrm{SO}_{4}$ and $1.2 \%(\mathrm{w} / \mathrm{v}) \mathrm{H}_{3} \mathrm{PO}_{4}$, liquid to solid ratio $3 \mathrm{~mL} / \mathrm{g}, 130^{\circ} \mathrm{C}$, and $30 \mathrm{~min}$. The concentrations of acetic acid, furfural, and HMF are 27.4, 8.0, and $0.7 \mathrm{~g} / \mathrm{L}$, respectively. These are, to the best of our knowledge, the highest total sugar and xylose concentrations in hydrolysates ever reported for acid-catalyzed hydrolysis of EFB. The two-step hydrolysis increased the xylose concentration compared to the onestep process but at a cost of reduced xylose yield due to the severer sugar degradation. Therefore, a compromise between high sugar concentration and high sugar yield must be considered for practical applications. It is worth mentioning that, during the acid-catalyzed hydrolysis, only hemicellulose sugars are stripped into the hydrolysate while the majority of cellulose is still existing in the solid form as a cellulose-lignin complex, which needs to be further converted to glucose either chemically or enzymatically before it can be utilized as a carbon source for fermentation by most microbes. The maximal glucose concentrations ever reported were in excess of $190 \mathrm{~g} / \mathrm{L}$ by acid hydrolysis of a hardwood (southern red oak) rather than oil palm empty fruit bunch [26]. The total sugar concentration of $114.4 \mathrm{~g} / \mathrm{L}$ obtained here is thought to be good enough for most commercial fermentation processes. 
TABLE 3: Comparison of total sugar and xylose concentrations in acid hydrolysate with literature results.

\begin{tabular}{|c|c|c|c|c|c|}
\hline Lignocellulose & Acid & Condition & Total sugars $(\mathrm{g} / \mathrm{L})$ & Xylose $(\mathrm{g} / \mathrm{L})$ & Reference \\
\hline Rapeseed straw (Brassica napus) & $1.76 \% \mathrm{H}_{2} \mathrm{SO}_{4}(\mathrm{w} / \mathrm{v})$ & $\begin{array}{c}152.6^{\circ} \mathrm{C}, 21 \mathrm{~min}, 15 \mathrm{~mL} \\
\text { liquid/g solid }\end{array}$ & 14 & 10.5 & {$[11]$} \\
\hline Sorghum straw & $6 \% \mathrm{HCl}(\mathrm{w} / \mathrm{w})$ & $\begin{array}{c}122^{\circ} \mathrm{C}, 70 \mathrm{~min}, 10 \mathrm{~g} \\
\text { liquid/g solid }\end{array}$ & 20 & 16.2 & {$[15]$} \\
\hline Silvergrass, rice straw, and bagasse & $1-3 \% \mathrm{H}_{2} \mathrm{SO}_{4}(\mathrm{w} / \mathrm{w})$ & $\begin{array}{l}121^{\circ} \mathrm{C}, 10-180 \mathrm{~min}, \\
10 \mathrm{~mL} \text { liquid/g solid }\end{array}$ & $27.9 / 28.1 / 29.8$ & $24.2 / 21.9 / 21.7$ & {$[16]$} \\
\hline $\mathrm{EFB}$ & $2 \% \mathrm{H}_{2} \mathrm{SO}_{4}(\mathrm{w} / \mathrm{w})$ & $\begin{array}{c}119^{\circ} \mathrm{C}, 60 \mathrm{~min}, 8 \mathrm{~g} \\
\text { liquid/g solid }\end{array}$ & $\mathrm{NA}^{*}$ & 31.1 & {$[1]$} \\
\hline Sugarcane bagasse & $3 \% \mathrm{H}_{2} \mathrm{SO}_{4}$ & $\begin{array}{c}121^{\circ} \mathrm{C}, 40 \mathrm{~min}, 4 \mathrm{~mL} \\
\text { liquid/g solid }\end{array}$ & NA & 57.3 & [9] \\
\hline $\mathrm{EFB}$ & $3 \% \mathrm{H}_{2} \mathrm{SO}_{4}$ and $1.2 \% \mathrm{H}_{3} \mathrm{PO}_{4}(\mathrm{w} / \mathrm{v})$ & $\begin{array}{c}130^{\circ} \mathrm{C}, 30 \mathrm{~min}, 3 \mathrm{~mL} \\
\text { liquid/g solid }\end{array}$ & 83.0 & 69.5 & $\begin{array}{c}\text { Step } 1 \\
\text { in this study }\end{array}$ \\
\hline $\mathrm{EFB}$ & Hydrolysate from step 1 & $\begin{array}{c}130^{\circ} \mathrm{C}, 36 \mathrm{~min}, 3 \mathrm{~mL} \\
\text { liquid/g solid }\end{array}$ & 114.4 & 93.5 & $\begin{array}{c}\text { Step } 2 \\
\text { in this study }\end{array}$ \\
\hline
\end{tabular}

${ }^{*}$ Not available in the reference.

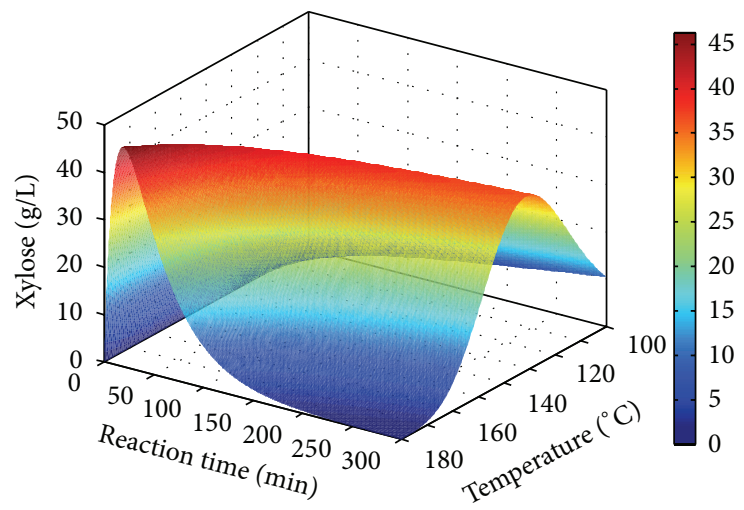

(a)

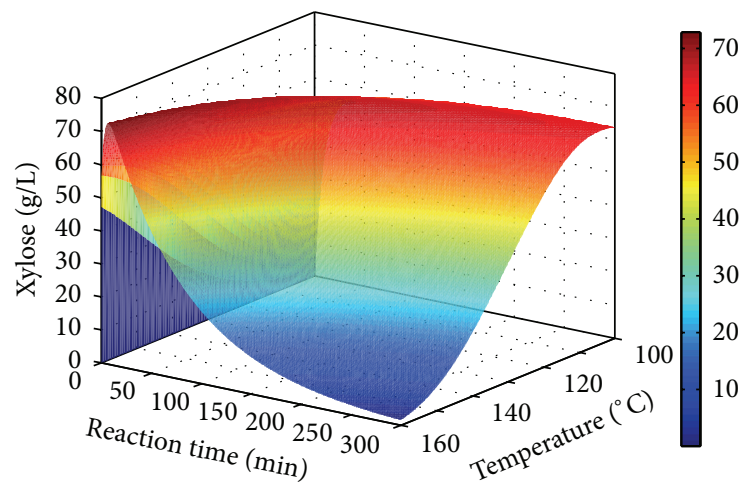

(c)

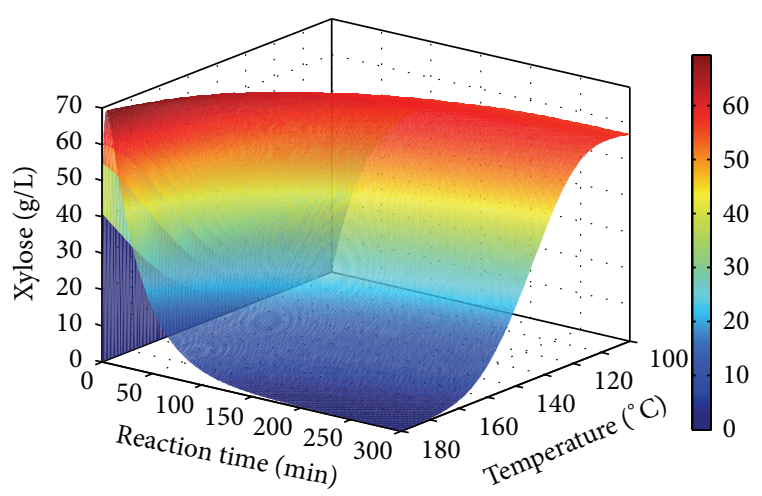

(b)

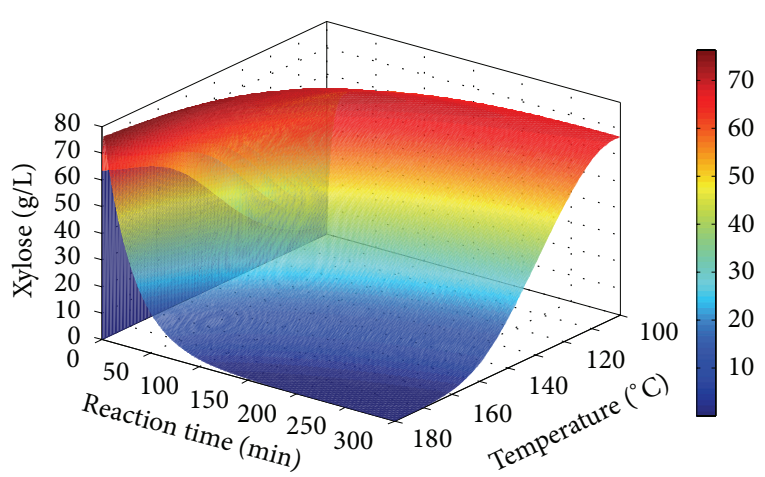

(d)

Figure 4: Predicted 3-dimentional changes of xylose concentration at different acid concentrations. (a) $1 \%$ (w/v) $\mathrm{H}_{2} \mathrm{SO}_{4}$ and $0.4 \%$ (w/v) $\mathrm{H}_{3} \mathrm{PO}_{4}$; (b) $2 \%(\mathrm{w} / \mathrm{v}) \mathrm{H}_{2} \mathrm{SO}_{4}$ and $0.8 \%$ (w/v) $\mathrm{H}_{3} \mathrm{PO}_{4}$; (c) $2.5 \%$ (w/v) $\mathrm{H}_{2} \mathrm{SO}_{4}$ and $1 \%$ (w/v) $\mathrm{H}_{3} \mathrm{PO}_{4}$; (d) $3 \%$ (w/v) $\mathrm{H}_{2} \mathrm{SO}_{4}$ and $1.2 \%\left(\mathrm{w} / \mathrm{v}\right.$ ) $\mathrm{H}_{3} \mathrm{PO}_{4}$. Other assumed conditions: liquid to solid ratio $3 \mathrm{~mL} / \mathrm{g}, 100-180^{\circ} \mathrm{C}$.

\section{Conclusions}

Two-step acid-catalyzed hydrolysis of EFB at low liquid to solid ratios to get high sugar concentrations in hydrolysates was investigated and optimized based on the biphasic model. A total sugar concentration of $83.0 \mathrm{~g} / \mathrm{L}$ and a xylose concentration of $69.5 \mathrm{~g} / \mathrm{L}$ with a xylose yield of $84.0 \%$ were experimentally achieved in the first step hydrolysis under the optimal conditions. The total sugar and xylose concentrations were further increased to $114.4 \mathrm{~g} / \mathrm{L}$ and $93.5 \mathrm{~g} / \mathrm{L}$, respectively, in the second step hydrolysis with a total xylose yield of $56.5 \%$. These are, to the best of our knowledge, the highest 


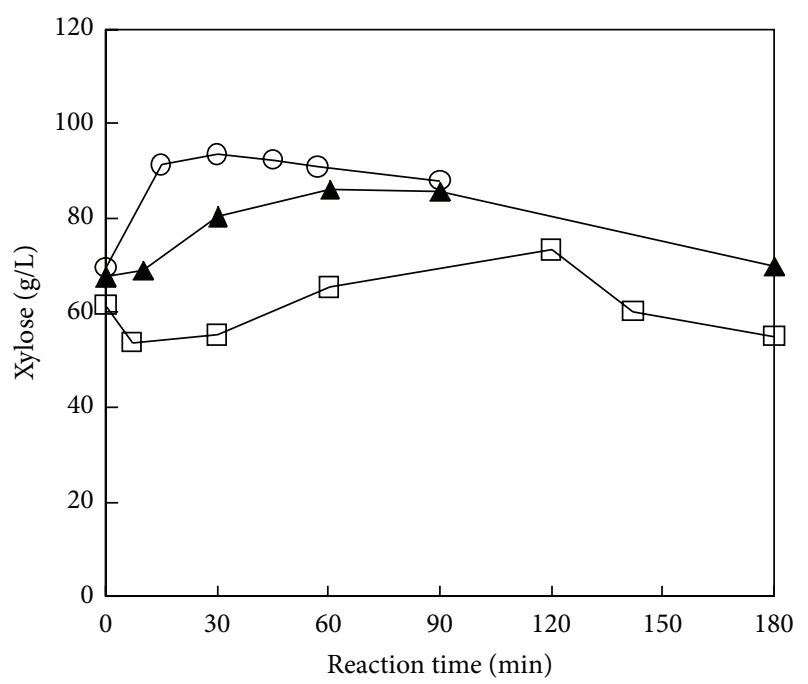

FIGURE 5: Time courses of xylose concentration in second step EFB hydrolysis at different acid concentrations. $\square: 2 \%(\mathrm{w} / \mathrm{v}) \mathrm{H}_{2} \mathrm{SO}_{4}$ and $0.8 \%(\mathrm{w} / \mathrm{v}) \mathrm{H}_{3} \mathrm{PO}_{4} ; \mathbf{\Delta}: 2.5 \%(\mathrm{w} / \mathrm{v}) \mathrm{H}_{2} \mathrm{SO}_{4}$ and $1 \%(\mathrm{w} / \mathrm{v}) \mathrm{H}_{3} \mathrm{PO}_{4} ; \mathrm{O}$ : $3 \%(\mathrm{w} / \mathrm{v}) \mathrm{H}_{2} \mathrm{SO}_{4}$ and $1.2 \%(\mathrm{w} / \mathrm{v}) \mathrm{H}_{3} \mathrm{PO}_{4}$. Other conditions: liquid to solid ratio $3 \mathrm{~mL} / \mathrm{g}, 130^{\circ} \mathrm{C}$.

total sugar and xylose concentrations in hydrolysates ever reported for acid-catalyzed hydrolysis of EFB.

\section{Conflict of Interests}

The authors declare that there is no conflict of interests regarding the publication of this paper.

\section{Acknowledgments}

This work is supported by the Science and Engineering Research Council (SERC) of the Agency for Science, Technology and Research (A*STAR) under the Value-Added Chemicals from Lignocellulose (VACL) Program (SERC Grant nos. 0921590132, ICES/10-574A01, and NUS/279-000-308-305).

\section{References}

[1] S. H. A. Rahman, J. P. Choudhury, A. L. Ahmad, and A. H. Kamaruddin, "Optimization studies on acid hydrolysis of oil palm empty fruit bunch fiber for production of xylose," Bioresource Technology, vol. 98, no. 3, pp. 554-559, 2007.

[2] A. Hassan, A. A. Salema, F. N. Ani, and A. A. Bakar, "A review on oil palm empty fruit bunch fiber-reinforced polymer composite materials," Polymer Composites, vol. 31, no. 12, pp. 2079-2101, 2010.

[3] D. Piarpuzán, J. A. Quintero, and C. A. Cardona, "Empty fruit bunches from oil palm as a potential raw material for fuel ethanol production," Biomass and Bioenergy, vol. 35, no. 3, pp. 1130-1137, 2011.

[4] D. Zhang, Y. L. Ong, Z. Li, and J. C. Wu, "Optimization of dilute acid-catalyzed hydrolysis of oil palm empty fruit bunch for high yield production of xylose," Chemical Engineering Journal, vol. 181-182, pp. 636-642, 2012.
[5] M. Jawaid and H. P. S. Abdul Khalil, "Cellulosic/synthetic fibre reinforced polymer hybrid composites: a review," Carbohydrate Polymers, vol. 86, no. 1, pp. 1-18, 2011.

[6] J.-H. Kim, D. E. Block, S. P. Shoemaker, and D. A. Mills, "Conversion of rice straw to bio-based chemicals: an integrated process using Lactobacillus brevis," Applied Microbiology and Biotechnology, vol. 86, no. 5, pp. 1375-1385, 2010.

[7] A. K. Chandel, C. ES, R. Rudravaram, M. L. Narasu, L. V. Rao, and P. Ravindra, "Economics and environmental impact of bioethanol production technologies: an appraisal," Biotechnology and Molecular Biology Reviews, vol. 2, no. 1, pp. 14-32, 2007.

[8] R. C. Kuhad and A. Singh, "Lignocellulose biotechnology. Current and future prospects," Critical Reviews in Biotechnology, vol. 13, no. 2, pp. 151-172, 1993.

[9] R. Fogel, R. R. Garcia, R. da Silva Oliveira, D. N. M. Palacio, L. da Silva Madeira, and N. Pereira Jr., "Optimization of acid hydrolysis of sugarcane bagasse and investigations on its fermentability for the production of xylitol by Candida guilliermondii," Applied Biochemistry and Biotechnology A, vol. 122, no. 1-3, pp. 741-752, 2005.

[10] C. Martin, B. Alriksson, A. Sjöde, N.-O. Nilvebrant, and L. J. Jönsson, "Dilute sulfuric acid pretreatment of agricultural and agro-industrial residues for ethanol production," Applied Biochemistry and Biotechnology, vol. 137-140, no. 1-12, pp. 339352, 2007.

[11] T.-S. Jeong, B.-H. Um, J.-S. Kim, and K.-K. Oh, "Optimizing dilute-acid pretreatment of rapeseed straw for extraction of hemicellulose," Applied Biochemistry and Biotechnology, vol. 161, no. 1-8, pp. 22-33, 2010.

[12] A. L. Demain, "Small bugs, big business: the economic power of the microbe," Biotechnology Advances, vol. 18, no. 6, pp. 499-514, 2000.

[13] H. Tao, R. Gonzalez, A. Martinez et al., "Engineering a homoethanol pathway in Escherichia coli: increased glycolytic flux and levels of expression of glycolytic genes during xylose fermentation," Journal of Bacteriology, vol. 183, no. 10, pp. 29792988, 2001.

[14] M. Sedlak, H. J. Edenberg, and N. W. Y. Ho, "DNA microarray analysis of the expression of the genes encoding the major enzymes in ethanol production during glucose and xylose co-fermentation by metabolically engineered Saccharomyces yeast," Enzyme and Microbial Technology, vol. 33, no. 1, pp. 1928, 2003.

[15] A. Herrera, S. J. Téllez-Luis, J. A. Ramírez, and M. Vázquez, "Production of xylose from sorghum straw using hydrochloric acid," Journal of Cereal Science, vol. 37, no. 3, pp. 267-274, 2003.

[16] G.-L. Guo, W.-H. Chen, W.-H. Chen, L.-C. Men, and W.S. Hwang, "Characterization of dilute acid pretreatment of silvergrass for ethanol production," Bioresource Technology, vol. 99, no. 14, pp. 6046-6053, 2008.

[17] L. Yan, H. Zhang, J. Chen et al., "Dilute sulfuric acid cycle spray flow-through pretreatment of corn stover for enhancement of sugar recovery," Bioresource Technology, vol. 100, no. 5, pp. 18031808, 2009.

[18] S. W. McKibbins, Kinetics of the Acid Catalyzed Conversion of Glucose to 5-Hydroxymethyl-2-Furaldehyde and Levulinic Acid, Department of Chemical Engineering, University of Wisconsin, Madison, Wis, USA, 1958. 
[19] S. W. McKibbins, J. F. Harris, J. F. Saeman, and W. K. Neill, "Kinetics of the acid-catalyzed conversion of glucose to 5hydroxymethyl-2-furaldehyde and levulinic acid," Forest Products Journal, vol. 12, no. 1, pp. 17-23, 1962.

[20] J. J. McParland, H. E. Grethlein, and A. O. Converse, "Kinetics of acid hydrolysis of corn stover," Solar Energy, vol. 28, no. 1, pp. 55-63, 1982.

[21] J. F. Saeman, "Kinetics of wood saccharification-hydrolysis of cellulose and decomposition of sugars in dilute acid at high temperature," Industrial and Engineering Chemistry, vol. 37, no. 1, pp. 43-52, 1945.

[22] S. E. Jacobsen and C. E. Wyman, "Cellulose and hemicellulose hydrolysis models for application to current and novel pretreatment processes," Applied Biochemistry and Biotechnology A, vol. 84-86, no. 1-9, pp. 81-96, 2000.

[23] Y. Lu and N. S. Mosier, "Kinetic modeling analysis of maleic acid-catalyzed hemicellulose hydrolysis in corn stover," Biotechnology and Bioengineering, vol. 101, no. 6, pp. 1170-1181, 2008.

[24] T. Kobayashi and Y. Sakai, "Hydrolysis rate of pentosan of hardwood in dilute sulfuric acid," Bulletin of the Chemical Society of Japan, vol. 20, no. 1, pp. 1-7, 1956.

[25] A. Esteghlalian, A. G. Hashimoto, J. J. Fenske, and M. H. Penner, "Modeling and optimization of the dilute-sulfuricacid pretreatment of corn stover, poplar and switchgrass," Bioresource Technology, vol. 59, no. 2-3, pp. 129-136, 1997.

[26] J. F. Harris, A. J. Baker, A. H. Conner et al., Two-Stage, Dilute Sulfuric Acid Hydrolysis of Wood: An Investigation of Fundamentals, U.S. Department of Agriculture, Forest Service, Forest Products Laboratory, Madison, Wis, USA, 1985. 

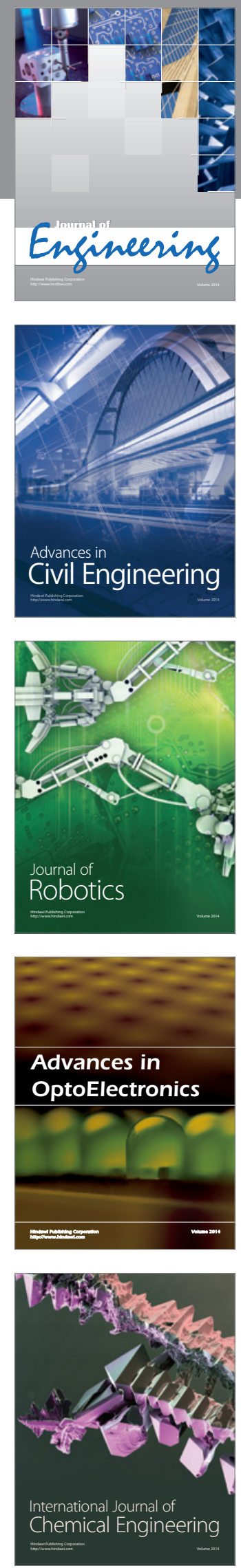

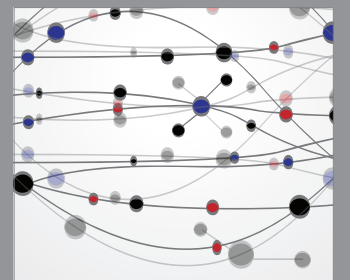

The Scientific World Journal
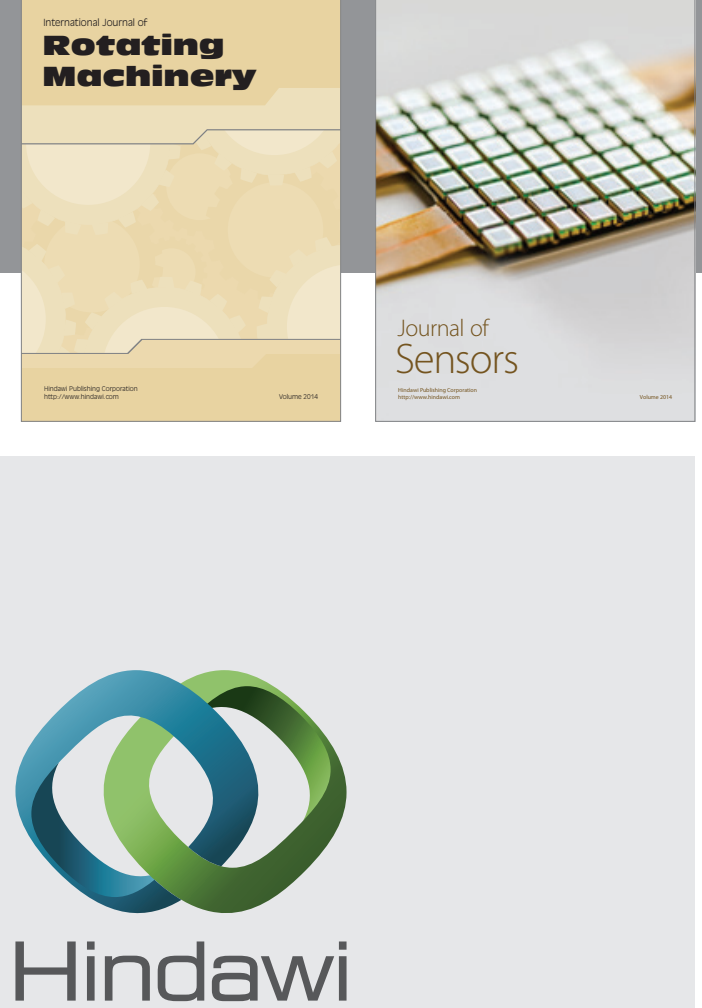

Submit your manuscripts at http://www.hindawi.com
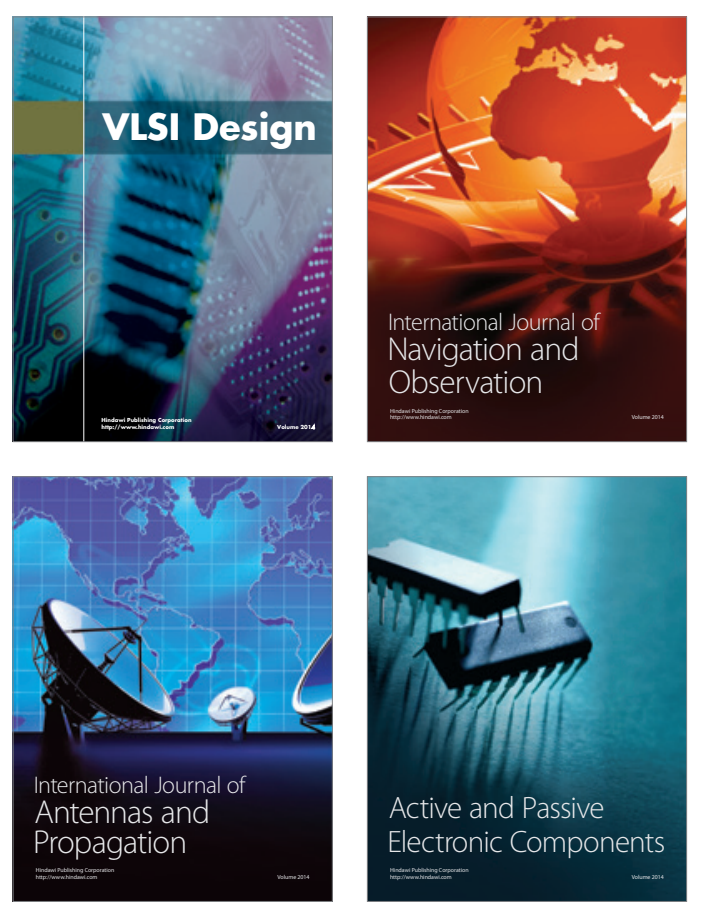
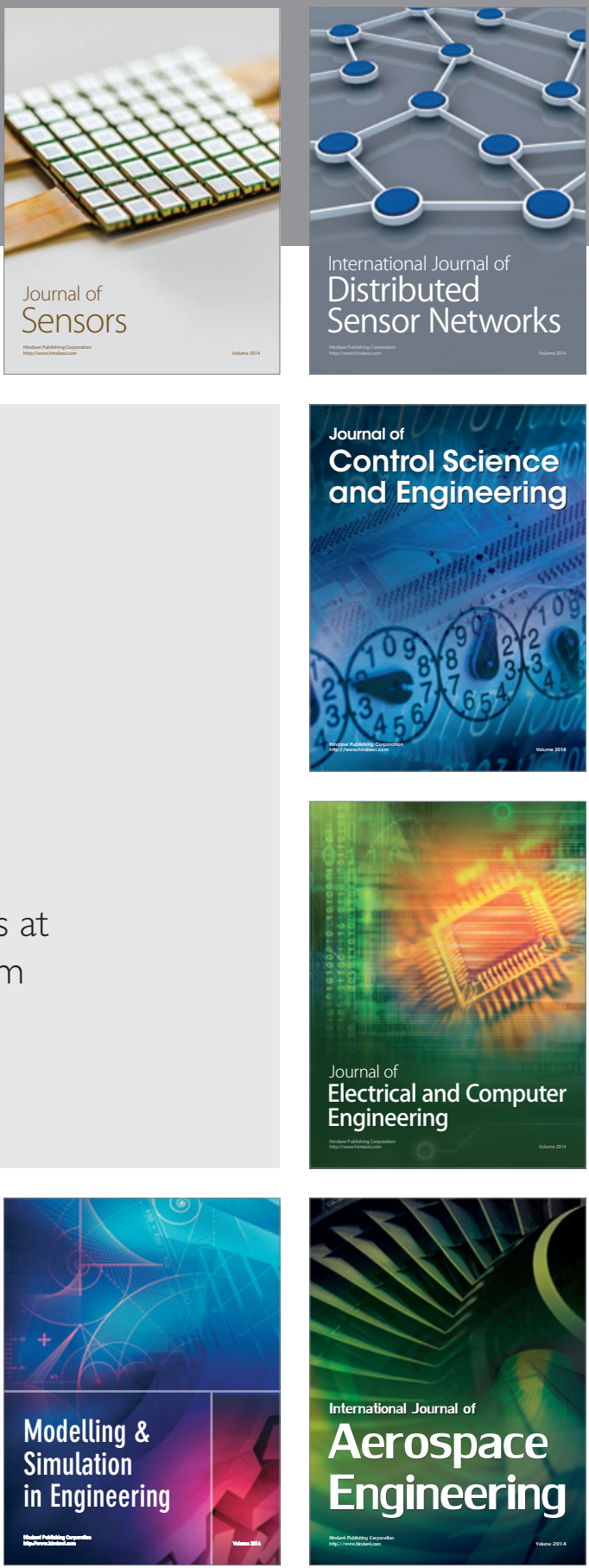

Journal of

Control Science

and Engineering
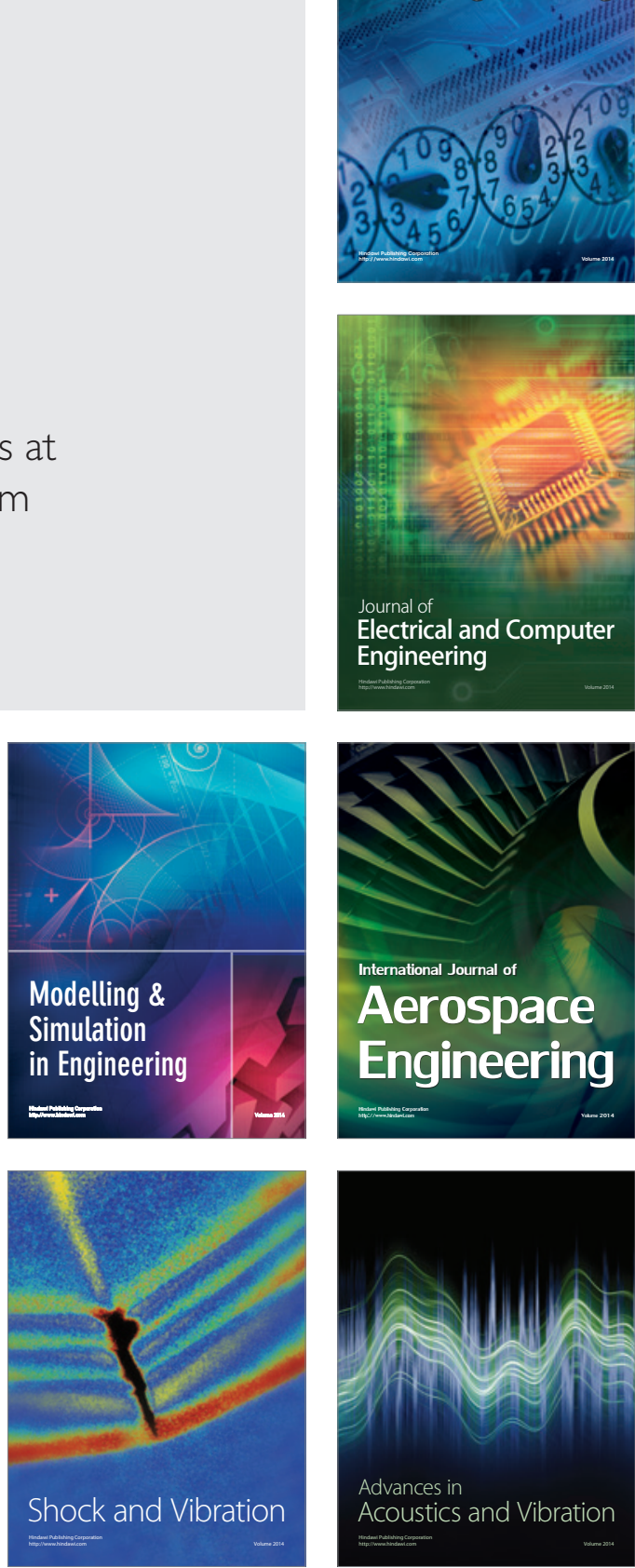